\title{
An analysis of the challenges for groundwater governance during shale gas development in South Africa
}

\author{
K Pietersen ${ }^{11 *}$, T Kanyerere ${ }^{2}$, A Levine ${ }^{3}$, A Matshini ${ }^{2}$ and HE Beekman' \\ 'SLR Consulting (Pty) Ltd, P.O. Box 2310, Durbanville 7550, South Africa \\ ${ }^{2}$ University of the Western Cape, Private Bag X17, Bellville 7535, South Africa \\ ${ }^{3}$ University of California, Santa Cruz, CA, USA
}

\begin{abstract}
As a prelude to potential development of South Africa's shale gas resources, it is critical to develop and implement effective groundwater governance arrangements. Existing policies and plans were analysed to determine whether critical gaps or barriers exist that could potentially lead to impacts on groundwater systems. Ten high-priority governance challenges were identified: (a) defining relevant metrics for baseline groundwater quality and availability; (b) developing guidelines for shale gas resource licensing, exploration, drilling, extraction, production, and completion; (c) defining and enforcing compliance monitoring systems; (d) dealing punitively with non-compliant operators; (e) mitigating and managing risks to prevent impairment of groundwater resources; (f) implementing a goal-based regulatory framework; $g$ ) enforcing strict chemical disclosure requirements; $(\mathrm{h})$ coordinating across government departments and regulatory bodies meaningfully and productively; (i) implementing a framework for subsidiarity and support to local water management; and (j) providing an incentive framework that supports strong groundwater management and environmental protection. To overcome these challenges, it is recommended that a decentralised, polycentric, bottom-up approach involving multiple institutions is developed to adaptively manage shale gas development. This transition from the current rigid regulatory structure can foster cooperation and collaboration among key stakeholders. The use of a pro-active groundwater governance structure that can accommodate current, near-term, and long-term shale gas development is important for ensuring that future energy development in South Africa incorporates the influence of other simultaneous stressors such as climate (e.g. drought), landuse changes, population growth, industry, and competing demands for water.
\end{abstract}

Keywords: groundwater, water governance, shale gas, South Africa

\section{INTRODUCTION}

The hydrocarbon potential of South Africa's main Karoo Basin (Fig. 1) was confirmed in the 1960s/70s (Rowsell and De Swardt, 1976; Rowsell and Connan, 1979) and is receiving renewed attention for extracting prospective shale gas resources. The growing interest in shale gas is led by experiences in the United States of America (US) where production of shale gas increased ten-fold between 2006 and 2010 (McGlade et al., 2013). However, the need for mechanisms to ensure protection of groundwater resources has emerged as a critical issue (De Wit, 2011; Vengosh et al., 2014). Although efforts exist to understand the technical implications of shale gas development on groundwater in South Africa (Steyl et al., 2012), limited attention has been given to the broader groundwater governance issues, both in South Africa and internationally. The paper begins by comprehensively summarising the groundwater concerns related to shale gas development and regulatory lessons from international jurisdictions. A framework approach (Wijnen et al., 2012) is presented for the groundwater governance analysis. The framework is applied to the South African situation resulting in a gap and barrier analysis for effective groundwater governance relevant to shale gas development. Finally the issues resulting from the analysis are prioritised and recommendations made to overcome the groundwater governance challenges.

\footnotetext{
* To whom all correspondence should be addressed.

ฮ +27 219768870 / +27 62704 6350; e-mail: kpietersen@slrconsulting.com Received 20 April 2015; accepted in revised form 2 June 2016
}

\section{GROUNDWATER CONCERNS DURING SHALE GAS DEVELOPMENT}

Shale gas is produced from organic-rich mudrocks, which serve as the source and reservoir for the gas (GSA, 2012). The advent of hydraulic fracturing (HF) has enabled more cost-effective access to the target formations. The HF process entails the injection of thousands of cubic meters $\left(\mathrm{m}^{3}\right)$ of water, proppant and chemicals under high pressure through perforated casing, thereby increasing the permeability and providing a conduit for shale gas extraction. The build-up in pressure causes the shale formation to open existing or initiate new fractures. The proppant fills the fractures to keep them from closing.

Vengosh et al. (2014) provided an overview and synopsis of the potential risks to water resources from unconventional shale gas development in the US and identified four potential modes of water resource degradation: (a) shallow aquifers contaminated by fugitive natural gas (i.e. stray gas contamination) from leaking shale gas and conventional oil and gas wells, potentially followed by water contamination from hydraulic fracturing fluids and/ or contaminant mobilisation (such as salts, barium, strontium, bromium and naturally-occurring radioactive materials) from flowback or produced water from deeper formations; (b) surface water contamination from spills, leaks and the disposal of inadequately treated wastewater or hydraulic fracturing fluids; (c) accumulation of toxic and radioactive elements in soil and the sediments of rivers and lakes exposed to wastewater, flowback, or fluids used in hydraulic fracturing; and (d) the overuse of water resources, which can compromise the availability of water to support competing uses including potable water 


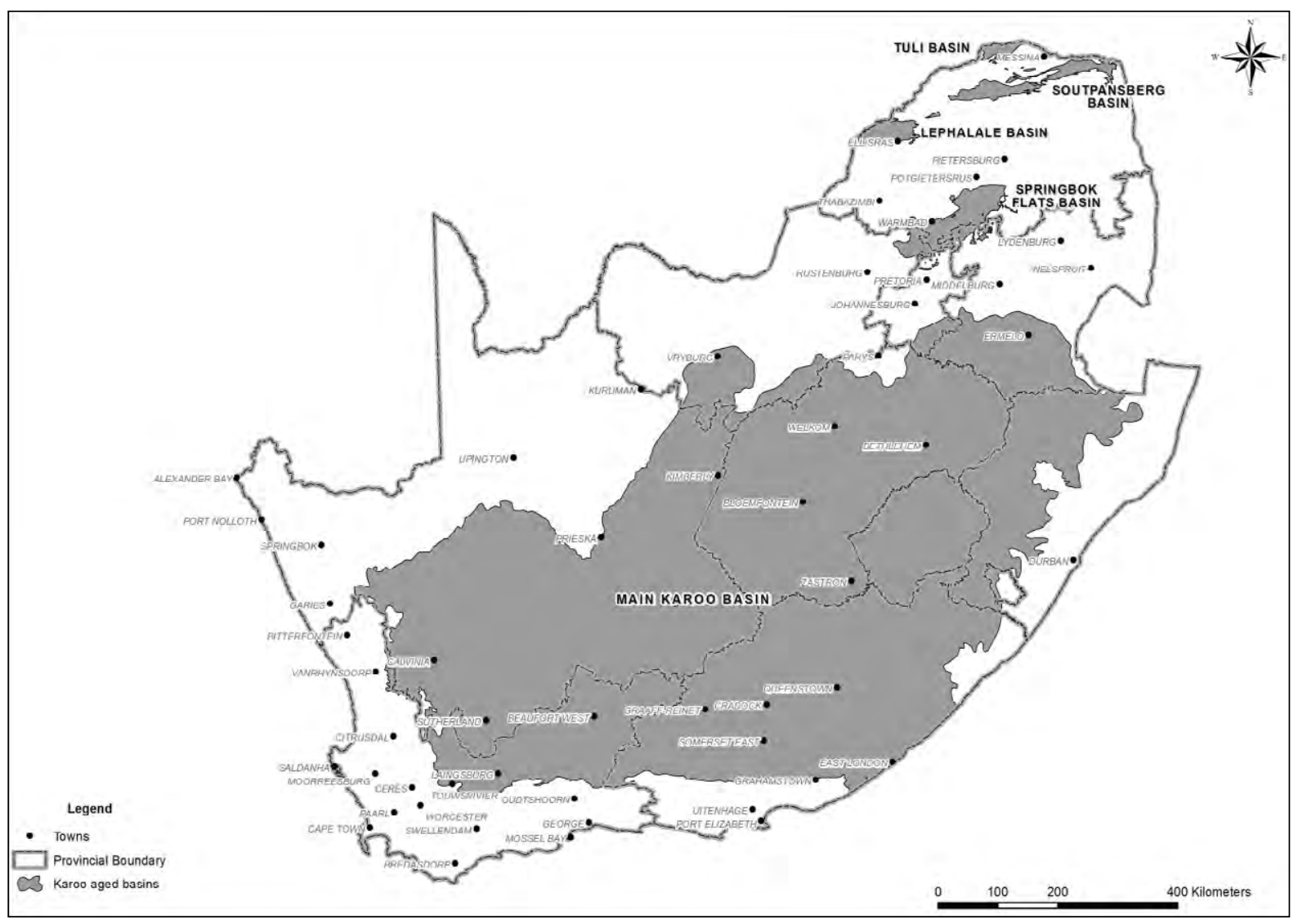

Figure 1

Location of the Karoo basins in South Africa

supplies, irrigation, and industry, particularly in water-limited environments or under drought conditions.

The most likely pathway for groundwater contamination is casing and cementing issues that affect well integrity (Darrah et al., 2014) as opposed to migration through subsurface fractures and faults (Darrah et al., 2014; Davies et al., 2014). Groundwater contamination can also occur from surface activities (Drollette et al., 2015; US EPA, 2015) related to shale gas production. For example, in a study evaluating groundwater contamination in the Marcellus Shale, a compound identified in flowback [water], 2-n-Butoxyethanol, was positively identified in nearby drinking water wells (Llewellyn et al., 2015). Part of the problem may have been wastewaters from a pit leak reported at the nearest gas well pad - the only nearby pad where wells were hydraulically fractured before the contamination incident (Llewellyn et al., 2015). In another study (Quast et al., 2016), tertiary butyl alcohol was discovered in groundwater near hydrocarbon extraction wells, but it was not possible to demonstrate any connections with hydraulic fracturing or other gas production activities. As reported in Table 1, a big concern is the amount of water used in shale gas production. Vengosh et al. (2014) reviewed reports and compiled data of the water consumption for shale gas development from the Marcellus, Barnett, Haynesville, Eagle Ford, Woodford Shale and Horn River in British Columbia, which showed that water use varies from 8000 to $100000 \mathrm{~m}^{3}$ per shale gas well (Table 1).

The widespread variability in use of water stems from differences in well borehole configuration and volume, hydrocarbon type, target oil or gas reservoir, and the drill year of the well (Gallegos et al., 2015). Over the years there have been advances in technologies related to water use efficiencies and also well integrity. Thus, according to Gallegos et al. (2015), hydraulic fracturing is not a one-size-fits-all operation; assumptions and generalisations regarding water use in hydraulic fracturing operations and the potential for environmental impacts should be made with caution.

\section{GROUNDWATER PROTECTION - REGULATORY LESSONS FROM INTERNATIONAL JURISDICTIONS}

It is important to recognise that groundwater management systems mostly fail due to inadequate governance arrangements (Foster and Garduño, 2013). There is perpetual tension between groundwater as a common resource and protecting the rights of private appropriation of groundwater for use. Societies, in general, have little interest in the actual state of groundwater resources, but tend to have very high levels of interest in the environmental, social and economic services associated with groundwater when it is left in situ or extracted for a specific use (Moench et al., 2012). Thus, groundwater is inherently vulnerable to the so-called 'tragedy of the commons' (Ostrom, 1999) in which actual users and potential polluters act solely in their individual short-term interest rather than taking into account long-term communal considerations (Foster and Garduño, 2013). Braune and Adams (2013), in their regional diagnosis of groundwater governance for the Sub-Saharan Africa region, found that there is a serious lack of capacity at national, river basin and local levels, inadequate resource monitoring and assessment, lack of institutional development at the important local level, and a general lack of awareness and appreciation of its role, which together have a major region-wide impact on social and economic development. 
As shale gas development expands globally, there is increasing evidence that potential hazards to groundwater resources can occur during drilling, well completion, site management (including development, closure, and post-closure), and production of shale gas. It is also evident that an effective regulatory regime is necessary for hazard mitigation. For South Africa, there is an opportunity to leverage international practices to develop effective regulatory and water governance mechanisms to ensure groundwater protection. In general, the current generation of regulatory approaches can be categorised as goal-based or prescriptive. A comparison of international regulatory and governance strategies that have been implemented in the United Kingdom (UK), Canada, Australia, and the US is useful for identifying approaches that are relevant to the South African context.

\section{Implications of goal-based vs. prescriptive regulation for groundwater governance}

The UK has a goal-based approach to regulation, which means that regulators set out goals, but operators are responsible for considering the means to achieve them according to the principle of minimising risks (The Royal Society and The Royal Academy of Engineering, 2012). This goal-based approach offers several advantages over prescriptive regulations (Penny et al., 2001): Firstly, with prescriptive regulations, the service provider is only required to carry out the mandated actions. If these actions prove to be insufficient to prevent subsequent problems, the service provider is not liable for rectifying any problems and the regulations are considered deficient. Thus, safety is viewed as the responsibility of the regulator and not the service provider. Secondly, prescriptive regulations tend to evolve from historic precedents and, as such, may not be aligned with current practices leading to unintended consequences such as limiting incentives for technical innovations. Thirdly, prescriptive regulations encode the best engineering practice at the time that they were written and rapidly become outdated and deficient where best practice is changing, e.g., with evolving technologies. Clearly, prescriptive safety regulations are unable to cope with a diversity of design solutions. In fact, prescriptive regulations may prove to be counter-productive and preclude the service
TABLE 1

Water use and wastewater production per shale gas well in different shale gas basins in the US (Vengosh et al., 2014)

\begin{tabular}{|l|c|c|}
\hline Basin & $\begin{array}{c}\text { Water use per } \\
\text { well } \mathbf{( m}^{\mathbf{3}} \mathbf{)}\end{array}$ & $\begin{array}{c}\text { Wastewater per } \\
\text { well } \mathbf{( m}^{\mathbf{3}} \mathbf{)}\end{array}$ \\
\hline $\begin{array}{l}\text { Horn River Basin (British } \\
\text { Columbia, Canada) }\end{array}$ & 50000 & \\
\hline $\begin{array}{l}\text { Marcellus Shale, Pennsylvania } \\
(<2010)\end{array}$ & $7700-38000$ & \\
\hline Marcellus Shale (2008-2011) & $11500-19000$ & 5200 \\
\hline Marcellus Shale (2012) & & 3500 \\
\hline Woodford Shale, Oklahoma & 16000 & \\
\hline Barnett Shale (Texas) & 10000 & \\
\hline Haynesville, Texas & 21500 & \\
\hline Eagle Ford. Texas & 16100 & \\
\hline Niobrara, Colorado (2012) & 13000 & 4000 \\
\hline
\end{tabular}

provider from adopting current best practice. The Government of Alberta in Canada is piloting a risk-based regulation approach that accommodates the specific characteristics of each shale gas play (Fig. 2). As development increases from initial exploratory wells to full-scale commercial development, regional impacts will be addressed through increased emphasis on planning and collaboration among operators in a play (ERCB, 2013). Such an approach may be useful for the South African situation.

\section{Regulation vs. the practice regarding disclosure of hydraulic injection fluid}

Regulatory approaches that require oversight of hydraulic fracturing injection fluids vary. The effectiveness of a disclosure rule depends on a number of important factors, including: when disclosure is made, what information is provided, and whether the information is provided in a manner that is accessible to those who seek it (McFeeley, 2012). Examples of typical chemical additives that are used for shale gas energy development are listed in Table 2. The amounts and combinations of the chemicals that are used vary based on the geological and geochemical characteristics of each site and economic factors. It is important to note that research into alternative formulations is ongoing with an

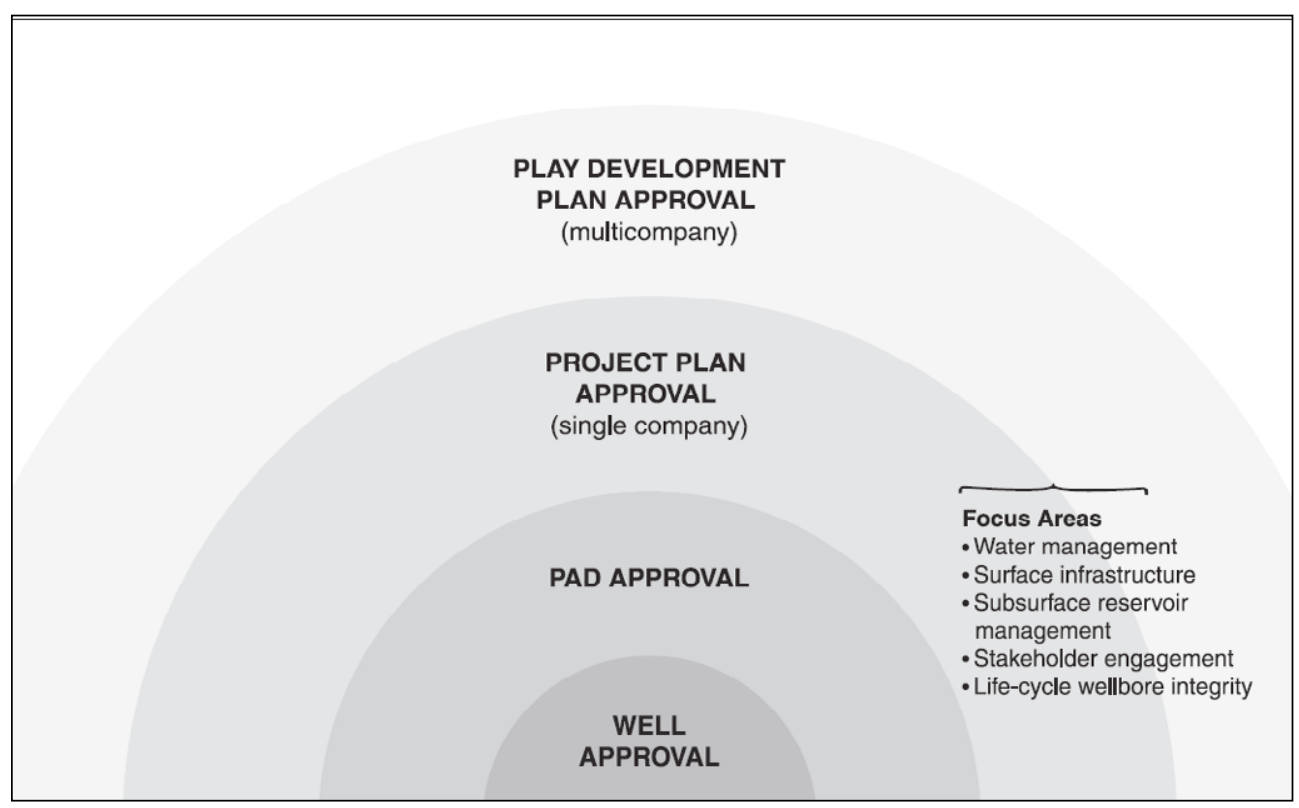

Figure 2

Shale gas resource [regulatory] framework $(E R C B, 2013)$ 
emphasis on cost-effective environmentally 'friendly' chemicals that can be readily biodegraded or recovered for reuse.

Requirements for disclosure of the chemical formulations are highly variable. FracFocus is an example of a chemical disclosure registry, that started as a voluntary disclosure site to provide the public access to reported chemicals used for hydraulic fracturing within their area (FracFocus, 2014). Typically, the commercial names of the chemicals are provided with generic information from material safety data sheets (MSDS). However, details are lacking on the quantities of chemicals that are injected. The US lacks national requirements and individual states have the authority to implement local regulations. The absence of consistent national or state-by-state approaches has resulted in several noteworthy shortcomings including nondisclosure of proprietary or 'trade secret' mixtures, insufficient enforcement or penalties for reporting inaccurate or incomplete information, and timelines that allow for after-the-fact reporting (Maule et al., 2013). Canada has established a version of FracFocus to assist in chemical disclosure. All companies regulated by the Canada Oil and Gas Operations Act must post details of their practices and the fluids they used on the FracFocus website within 30 days after a fracturing operation is complete (Komnenic, 2013). The problem with this practice is that there is no opportunity for stakeholders to raise concerns in advance of chemical injection. In the case of Western Australia, all operators are responsible for disclosing all down-hole chemicals and substances in their Environment Plan, which must be made publically available before drilling (Department of Mines and Petroleum, 2013). Similarly, the UK requires complete disclosure of all fracturing fluid additives before drilling.

\section{The credibility of compliance monitoring and enforcement}

Compliance monitoring and enforcement provide credibility and serve as a backstop to an effective governance regime (Konschnik and Boling, 2014). Some useful perspectives can be gleaned from reviewing some of the state-based approaches that are prevalent in the US. Based on an audit of the Pennsylvania (PA) Department of Environmental Protection (DEP) performance related to shale gas development 2009-2012, several issues were identified (Department of the Auditor General, 2014). A critical deficiency was that the PA DEP did not routinely and consistently issue orders requiring oil and gas operators to remediate adversely impacted water supplies as required by law. Another overall conclusion of the audit was that the PA DEP was unprepared to meet the challenges imposed by the rapid expansion of shale gas development and lacked an adequately trained workforce to manage the unprecedented workloads (Department of the Auditor General, 2014). South Africa can incorporate the outcomes of international experience in the regulatory planning process. For example, based on the challenges faced by the PA DEP, South Africa will need to ramp-up its compliance and monitoring institutional framework to deal with the challenges of shale gas development. This includes (Department of the Auditor General, 2014): (a) becoming a stronger regulator; (b) use of enforcement powers consistently; (c) issuing clear and understandable directives meeting statutory guidelines; (d) timely and thorough investigation and resolution of complaints and issues; (e) controls on how complaints are received, tracked, investigated, resolved, and communicated, i.e., a fully developed complaint management system and procedures; (f) training and hiring competent compliance and monitoring and enforcement officers; (g) implementing and validating electronic-inspection processes so that information is accurate and timely; (h) implementing a waste management manifest system to track all liquid and solid wastes; and (i) developing a transparent information system that provides stakeholders with ready-access to complete, clear, and pertinent information. Clearly, there is an urgent need for a dedicated capacity and competence development programme.

\begin{tabular}{|c|c|c|}
\hline \multicolumn{3}{|c|}{$\begin{array}{c}\text { TABLE } 2 \\
\text { Common chemical additives for hydraulic fracturing (Vidic et al., 2013) }\end{array}$} \\
\hline Additive type & Example compounds & Purpose \\
\hline Acid & Hydrochloric acid & $\begin{array}{l}\text { Clean out the wellbore, dissolve minerals and } \\
\text { initiate cracks in rock }\end{array}$ \\
\hline Friction reducer & $\begin{array}{l}\text { Polyacrylamide } \\
\text { Petroleum distillate } \\
\text { Isopropanol } \\
\text { Acetaldehyde }\end{array}$ & $\begin{array}{l}\text { Minimise friction between the fluid and the } \\
\text { pipe. }\end{array}$ \\
\hline Corrosion inhibitor & $\begin{array}{l}\text { Isopropanol } \\
\text { Acetaldehyde }\end{array}$ & Prevent corrosion of pipe by diluted acid. \\
\hline Iron control & $\begin{array}{l}\text { Citric acid } \\
\text { Thioglycolic acid }\end{array}$ & Prevent precipitation of metal oxides. \\
\hline Biocide & $\begin{array}{l}\text { Glutaraldehyde } \\
\text { 2,2-dibromo-3-nitrilopropionamide }\end{array}$ & Bacterial control. \\
\hline Gelling agent & Gua/xantham gum or hydroxyethyl cellulose & Thicken water to suspend the sand \\
\hline Cross linker & Borate salts & Maximise fluid velocity at high temperatures \\
\hline Breaker & $\begin{array}{l}\text { Ammonium persulfate } \\
\text { Magnesium peroxide }\end{array}$ & Promote breakdown of gel polymers \\
\hline Oxygen scavenger & Ammonium bisulfite & $\begin{array}{l}\text { Remove oxygen from fluid to reduce pipe } \\
\text { corrosion. }\end{array}$ \\
\hline $\mathrm{pH}$ adjustment & Potassium or sodium hydroxide or carbonate & $\begin{array}{l}\text { Maintain effectiveness of other compounds } \\
\text { (such as cross linker). }\end{array}$ \\
\hline Proppant & Silica Quartz Sand & Keep fractures open. \\
\hline Scale inhibitor & Ethylene glycol & Reduce deposition on pipes. \\
\hline Surfactant & $\begin{array}{l}\text { Ethanol } \\
\text { Isopropyl alcohol } \\
\text { 2-butoxyethanol }\end{array}$ & Decrease surface tension to allow water recovery \\
\hline
\end{tabular}




\section{METHODS}

The overarching goal of this paper is to develop a framework relevant to unconventional shale gas energy in South Africa that builds upon the current state of knowledge. To achieve this goal, numerous sources of information (peer-reviewed journal articles, books and published reports; interviews with international and national experts and regulators; and field visits to operational shale gas sites) were compiled, reviewed, and mined using framework analysis (Dixon-Woods, 2011) and qualitative context analysis approaches (Srivastava and Thomson, 2009; Hsieh and Shannon, 2005). The framework method is an excellent tool for supporting thematic (qualitative content) analysis because it provides a systematic model for managing and mapping the data (Gale et al., 2013). First, data were categorised into three governance themes: policy setting, strategic, or local level governance based on Wijnen et al. (2012) (Table 3). Then, content analysis tools were used to develop hierarchical structures among the identified themes. In addition, directed approaches to content analysis were used to compare and rank the various themes (Srivastava and Thomson, 2009; Hsieh and Shannon, 2005).

\section{Framework for groundwater governance analysis}

In the South African situation, there are competing demands on the use of groundwater resources to meet domestic and agricultural needs. The governance of groundwater must take into consideration not only technical considerations but also social-ecological aspects. Frameworks and analytical tools are required to help understand complex governance regimes and the linkages between groundwater management and the corresponding effects on ecosystem services (Knüppe and PahlWostl, 2011). A working definition for groundwater governance
(Varady et al., 2012) is: the process by which groundwater is managed through the application of responsibility, participation, information availability, transparency, custom, and rule of law. In essence, it is the art of coordinating administrative actions and decision making between and among different jurisdictional levels - one of which may be global (Varady et al., 2012). Accordingly, 'groundwater governance could be interpreted as the set of policies or decisions that moderates groundwater use and promote aquifer protection (Smidt and Satijn, 2013). It is important to distinguish governance from 'government' (who decides) and 'management' (what is done to implement decisions) (Smidt and Satijn, 2013).

The advantages of a framework approach include its flexibility to be adapted to specific country situations and its ability to highlight issues within the various levels (policy, strategic, and local) and across those levels (Wijnen et al., 2012). Flexibility is also necessary to accommodate the variation in concepts (incentives, enforcement, etc.) and tools (financial subsidies, regulation, etc.) that may be applied at each level (Table 3). The framework is appropriate for analysis in this paper because it is based on original and real cases thereby allowing within-case and between-case analysis, besides being dynamic, systematic and comprehensive in its application (Srivastava and Thomson, 2009).

\section{Application of the framework analysis in South African context}

The framework categories identified in Table 3 were adapted to the South African situation and used to analyse the groundwater governance provisions for shale gas development (Table 4). The capacity of existing groundwater governance to address the stages of shale gas developed was reviewed in the context of policy setting, strategic, and local governance practices.

\begin{tabular}{|c|}
\hline $\begin{array}{l}\text { TABLE } 3 \\
\text { A framework for analysing and assessing groundwater governance (Wijnen et al., 2012) }\end{array}$ \\
\hline Policy setting: the nation establishes its objectives for groundwater \\
\hline $\begin{array}{l}\text { - Groundwater policies within overall water policy e.g.: } \\
\text { - Sustainability in quantity and quality } \\
\text { - Setting policies on efficiency in allocation and use within and between sectors } \\
\text { - Equity by ensuring fair access and protection of water rights } \\
\text { - Through an interactive process, water policy and the policies of other sectors are aligned }\end{array}$ \\
\hline $\begin{array}{l}\text { Strategic level governance: setting up the institutions and instruments to align stakeholder behaviour and actual outcomes } \\
\text { with policy objectives }\end{array}$ \\
\hline $\begin{array}{l}\text { - An integrated water resource management (IWRM) planning function capable of allocating water in line with society's policy goals } \\
\text { - A framework of laws, rights and regulatory instruments adapted to the context } \\
\text { - An incentive framework (prices, subsidies, trade controls etc.) that supports good groundwater management } \\
\text { - A framework for subsidiarity and support to local water management } \\
\text { - Acquisition and management of information and knowledge, and communication with stakeholders }\end{array}$ \\
\hline $\begin{array}{l}\text { Local level governance: organisations and institutions that control actual outcomes on the ground and which respond in vary- } \\
\text { ing degrees to the rules and incentives from the strategic governance level }\end{array}$ \\
\hline $\begin{array}{l}\text { - Public agencies (ministry branches, local authorities, basin agencies), which could be expected to more or less reflect policies and strategic level } \\
\text { governance at the local level. These agencies may directly control part of the resource (e.g. municipal well fields) or they may influence outcomes } \\
\text { by the application of a regulatory regime, or by working in partnership with local collective management institutions or with individuals } \\
\text { - Local collective management institutions, including collective organisations; and rules, sanctions and dispute resolution mechanisms developed } \\
\text { by communities and interest groups } \\
\text { Individual well owners, whose well development and abstraction behaviour are (in the absence of respect of any other governance system) deter- } \\
\text { mined by individual, household or family goals }\end{array}$ \\
\hline
\end{tabular}




\section{The use of framework and content analysis for setting policies}

Based on the outcome of framework and content analyses for setting policies (Pietersen et al., 2012), it appears that the necessary policies and legislation are in place for effective groundwater governance in South Africa. The Department of Water and Sanitation (DWS) is in the process of developing regulations to control the water-related impacts from shale gas exploration and production. Currently, the National Water Act allows the Minister to regulate activities having a detrimental impact on water resources by declaring them controlled activities. For example, the DWS has declared exploration and production of natural oil and gas resources as a controlled activity under the National Water Act (DWS, 2015). The DWS recognises that it must be part of the total process from exploration to exploitation and remediation, and that it should ensure that detailed, reliable baseline information is established before production activities begin (Singh, 2014).

\section{Application of framework and content analyses on strategic governance level}

Evidence of how strategic groundwater governance has been integrated into the national water resource planning functions (Pietersen et al., 2011) is available in the DWS Groundwater Strategy (DWA, 2013). In terms of shale gas development, the necessary policies exist to protect groundwater resources. Existing South African legislation has comprehensive provisions for environmental protection. For example, the National Water Act specifies that water be left as an 'environmental Reserve' necessary for ecosystem functioning. However, there is a need to anticipate the kind of regulatory issues that might be encountered as part of shale gas exploration and exploitation. These would not necessarily be limited to environmental issues, but could include transport regulations, tax law and policy, employment issues, infrastructure, and other linkages to the resource extraction lifecycle. These issues, considered together, bear on the extent to which the benefits of shale gas extraction are broadened and maximised and reduce negative effects such as pollution.

It is important to recognise that coordinated regulatory systems require meaningful collaboration across government organisations, as well as the close involvement of other stakeholders including the energy companies, communities, citizens, unions and farmers. For example (IRGC, 2013), seven factors that are considered important for regulatory development include: (a) measurement and documentation of baseline conditions; (b) establishment of technical standards based on bestindustry practices; (c) implementation mechanisms (permits etc.); (d) oversight of industry compliance through inspections and enforcement; (e) financial viability of both the regulatory entity and the industry, including adequate mechanisms of financial assurance; and (f) liability of the operators for non-compliance. As discussed previously, the DWS has declared exploration and production of natural oil and gas from unconventional resources as a controlled activity under the National Water Act. Consideration of the above aspects is necessary because it ensures that activities not explicitly listed in the National Water Act are covered.

The framework and content analysis conducted for this paper confirms that South Africa has draft regulations to support proposed controlled activities and such regulations, currently in the formulation phase (Muir, 2014) include: (a) no-go areas for vulnerable communities and water resources; (b) phased authorisations - survey, exploration, production licences; (c) licence requirements for pipelines; (d) monitoring and reporting requirements with full public disclosure; (e) restrictions on HF chemical use and management; and (f) post decommissioning monitoring and financial provisioning. The next assignment for South Africa is to critically review the draft regulations and assess whether the combination of goal-based and prescriptive regulations are adequate to achieve the goals of socio-economic and environmental integrity for South Africa as a country.

\section{The analysis of local level governance: Framework and content analyses}

Using the framework and content analyses, four regulatory measures were identified relevant to local groundwater governance arrangements. The four measures include baseline measurements, licence review, transgressions, and groundwater protection.

\section{Baseline measurements}

Statistically rigorous baseline groundwater sampling prior to shale gas development is important for regulators to establish whether future activities contaminate water resources (Levine and Benotti, 2015). There is a lack of consensus on the specific monitoring parameters and the frequency of sampling; however, Cranch et al. (2014) recommend: (a) baseline water sampling should be required with certain radii of shale gas wells; (b) mandatory follow-up testing should occur at established intervals after completion of drilling; (c) baseline water sampling should test for a standard set of parameters; and (d) an independent third party should conduct the sampling and testing.

\section{Review of licences and setting conditions}

Each licence application needs to be critically reviewed for water use, potential groundwater contamination, and evidence of overexploitation (Vengosh et al., 2014). Key concerns are: (a) stray gas contamination; (b) groundwater contamination with other salts or other dissolved constituents; and (c) over-abstraction.

\section{Transgressions}

In the case of perceived transgressions, there needs to be a transparent procedure to enable stakeholders to express concerns and a systematic methodology for prioritising and responding to complaints. Each complaint must be dealt with in a professional, credible, timely, well-documented, and thorough manner. There should also be mechanisms for review of administrative decisions which include the judicial review regarding the prevention of pollution to groundwater. Such reviews will aid in protecting groundwater resources.

\section{Prevention of pollution to groundwater}

Several approaches are available for mitigating groundwater contamination. Some examples of innovative solutions include: disclosure of hydraulic fracturing fluids prior to injection (Maule et al., 2013); recycling flowback water and using treated produced water (naturally occurring water from the shale formations), if present, as water sources for shale gas operations (Vengosh et al., 2014; Mauter et al., 2014). However, many onsite technologies exist that can be used to recycle wastewater 
including: (a) promoting purpose-built facilities by industry for wastewater treatment (Hickenbottom et al., 2013); (b) adopting best-practice guidelines and promoting continual improvement in well construction and integrity (Vengosh et al., 2014); (c) forbidding wastewater disposal into waterways and underground injection of wastewater (Muir, 2014); (d) use closed-loop fluid systems for water storage and containment - ban open containment (Muir, 2014); (e) avoid areas that have large-scale faults or conduits for possible methane migration (KGEG, 2013); (f) use technologies to confirm hydraulic fracture growth is limited to the targeted formations (Gonzalez-Chavez et al., 2015); and (g) line well pads to minimise releases (Brantley, 2015).

\section{Analytical framework and content analysis}

Using the framework of Wijnen et al. (2012) and the content analysis of Hsieh and Shannon (2005), gaps and barriers were identified for reflective and analytical assessment. This type of gap and barrier analysis is a crucial first step to understanding the extent to which existing policies, regulatory and technical activities at both national and local levels contain adequate and effective groundwater governance provisions. In undertaking this analysis, any areas where parts of the groundwater governance provisions are not addressed represent a 'gap'. Similarly, an 'institutional barrier' is any policy or structure that prevents the implementation of policy setting, strategic governance, or local level governance to facilitate groundwater resource protection.
Each of the identified gaps and institutional barriers was categorised and colour-coded (Table 4) to reflect the magnitude of the gap: (a) green (3) - criteria are met; (b) amber (2) - criteria partially met; (c) red (1) - significant gap or absent.

An initial ranking of the identified gaps and barriers is provided in Table 5 as a first step towards prioritisation. Additional input is needed from stakeholders such as DWS and communities. Based on this initial ranking, the highest priority is to institute a baseline monitoring system. Based on the results in Table $4,28.6 \%$ of the specified criteria were completely met (green $=3), 42.8 \%$ of criteria were partially met (amber $=2$ ) and $28.6 \%$ had 'significant gaps or were absent' or unmet (red $=1$ ). For the institutional barriers, $48 \%$ of the specified criteria were partially met (amber $=2$ ) while $52 \%$ were scored as 'having significant gaps or absent' (red $=1$ ). These identified themes, categories and ranked orders reveal salient gaps and institutional barrier issues that should be considered when governing groundwater in the context of pre-, during and post-hydraulic fracturing activities associated with shale gas development.

\section{DISCUSSION}

This systematic analysis has highlighted many gaps and barriers that need to be addressed before shale gas development can take place at an industrial scale. Although the necessary policies are in place at a national level, governance gaps emerge at strategic and local levels. In addition, institutional barriers exist

\begin{tabular}{|c|c|c|c|c|}
\hline \multicolumn{5}{|c|}{$\begin{array}{c}\text { TABLE } 4 \\
\text { Effectiveness of governance provisions (gap and barrier analysis) }\end{array}$} \\
\hline Category & Context & Criterion & Gap & Institutional barrier \\
\hline \multirow[t]{4}{*}{ Setting policies } & \multirow{3}{*}{$\begin{array}{l}\text { Groundwater policies } \\
\text { within overall water policy }\end{array}$} & Sustainability in quantity and quality & 3 & 2 \\
\hline & & $\begin{array}{l}\text { Efficiency in allocation and use within and } \\
\text { between sectors }\end{array}$ & 3 & 2 \\
\hline & & $\begin{array}{l}\text { Equity by ensuring fair access and protec- } \\
\text { tion of water rights }\end{array}$ & 3 & 2 \\
\hline & \begin{tabular}{|l|} 
Cross-sector policy \\
coordination
\end{tabular} & $\begin{array}{l}\text { Coordination with other government } \\
\text { departments and regulatory bodies }\end{array}$ & 2 & 1 \\
\hline \multirow[t]{12}{*}{$\begin{array}{l}\text { Strategic level } \\
\text { governance }\end{array}$} & IWRM & $\begin{array}{l}\text { An IWRM planning function capable of } \\
\text { allocating water in line with society's policy } \\
\text { goals }\end{array}$ & 3 & 2 \\
\hline & \multirow[t]{4}{*}{$\begin{array}{l}\text { Laws, rights and regulatory } \\
\text { instruments }\end{array}$} & $\begin{array}{l}\text { A framework of laws, rights and regulatory } \\
\text { instruments adapted to the context }\end{array}$ & 3 & 2 \\
\hline & & Goal-based regulatory framework & 2 & 1 \\
\hline & & Disclosure of hydraulic injection fluid & 2 & 1 \\
\hline & & Compliance monitoring and enforcement & 2 & 1 \\
\hline & Incentive framework & $\begin{array}{l}\text { An incentive framework (prices, subsidies, } \\
\text { trade controls etc.) that supports good } \\
\text { groundwater management }\end{array}$ & 1 & 1 \\
\hline & $\begin{array}{l}\text { Subsidiarity and local } \\
\text { water management }\end{array}$ & $\begin{array}{l}\text { A framework for subsidiarity and support } \\
\text { to local water management }\end{array}$ & 3 & 1 \\
\hline & \multirow[t]{5}{*}{ Knowledge and capacity } & $\begin{array}{l}\text { Acquisition and management of informa- } \\
\text { tion and knowledge, and communication } \\
\text { with stakeholders }\end{array}$ & 2 & 2 \\
\hline & & Research and knowledge production & 2 & 2 \\
\hline & & Education and training & 2 & 2 \\
\hline & & Information and brokerage & 2 & 2 \\
\hline & & Network and service rendering & 2 & 2 \\
\hline \multirow{5}{*}{$\begin{array}{l}\text { Local level } \\
\text { governance }\end{array}$} & \multirow[t]{2}{*}{ Baseline measurements } & To detect groundwater pollution & 1 & 1 \\
\hline & & To determine resource status & 1 & 1 \\
\hline & Licences & Review of licences and setting conditions & 1 & 1 \\
\hline & Transgressions & Dealing with non-compliant operators & 1 & 1 \\
\hline & Prevention of pollution & Mitigation options in place & 1 & 1 \\
\hline
\end{tabular}


at all three governance levels. These issues need to be prioritised to ensure the appropriate attention is given to building capacity and skills in the South African public sector. For example, the need to establish baseline conditions before full-scale shale gas production starts has been stressed at many forums (Pietersen et al., 2014). In addition to the outcome of such forums, baseline measurement to detect groundwater pollution and determine resource status is the highest ranked priority (Table 5). Our findings, as shown in Table 5, are supported by evidence from the US and Australian experiences which demonstrate that, without relevant and accurate baseline data, it is difficult to scientifically establish a cause of contamination (CIWEM, 2014).

However, establishing a baseline groundwater monitoring system requires an understanding of the particular aquifer system, release mechanisms and migration pathways which form the basis of a conceptual hydrogeological model of the connections between sources, pathways and receptors (O'Brien et al., 2013). The collection of monitoring data will assist in understanding the aquifer system. There is an urgent need to develop a series of 3D models of the Karoo Basin to understand the groundwater systems and their behaviour. It is likely that new data will become available through shale gas projects, which will greatly enhance basin models, but the government will need to take steps to ensure that appropriate quality assurance measures are in place and that an honest broker is available to provide access to the information for researchers, industry, and other interested parties (Cook et al., 2013). The baseline measurements will be crucial to setting licence and monitoring conditions for shale gas development activities. The challenges of implementing regulations and enforcement are well articulated by the Royal Society and the Royal Academy of Engineering (2012), Penny et al. (2001) and Vengosh et al.(2014). Key regulatory considerations include: (a) establishing exclusion zones to protect drinking water supplies; (b) implementing mandatory monitoring systems that incorporate modern geochemical techniques; (c) promoting transparency and data sharing, including full disclosure of all hydraulic fracturing chemicals; (d) enforcing zero-discharge policy for untreated wastewater and establishing adequate treatment technologies that could prevent surface water contamination; and (e) promoting use of marginal waters, e.g., brackish water, and requiring recycling and reuse of water.

Licence conditions need to be defined with an emphasis on ensuring that all operations are protective of the water environment. A necessary facet of direct regulation is a system of inspection and enforcement, including adequate resources for [licence] review, inspection of specific sites, and some form of penalties against developers who violate the conditions of their licences (IRGC, 2013). However, the current challenges and workforce capacity limitations associated with processing and issuing of licence applications may limit progress.

Setting-up the necessary institutions to support groundwater governance at local level will be critical to safe and sustainable shale gas development. It is worth noting that worldwide environmental compliance and aquifer protection appears as a weak driver for collective management of groundwater resources (Moench et al., 2012) It can be argued that the issue of groundwater contamination in the Karoo from shale gas development focuses on economic considerations and livelihoods rather than groundwater protection per se. A number of barriers and gaps for groundwater governance need to be overcome before largescale shale gas development is initiated (e.g. Tables 4 and 5). Nevertheless, the knowledge and capacity (albeit in the private sector) exist to deal with the water-related impacts of shale gas development. The challenge remains to mobilise this capacity for the benefit of groundwater protection.

Five elements (freedom of information; the right to organise; enabling legal, regulatory and financial frameworks; balanced equiTable water rights systems; and dispute resolution systems) represent the basic foundation for institutional pluralism in water (Moench et al., 2012) and can be extrapolated for groundwater governance in the Karoo:

- Freedom of information: Where scientific and other information on groundwater conditions and the impacts of emerging problems or potential solutions are not part of the public domain, then the factual basis for effective contestation is undermined. Groups (whether in the government, civil society or the market) cannot be challenged, problems cannot be documented, and there is little factual basis for developing new management responses. Freedom of information is a basic enabling condition.

\begin{tabular}{|c|c|c|c|c|}
\hline \multicolumn{5}{|c|}{$\begin{array}{c}\text { TABLE } 5 \\
\text { Ranking and weighting of the criteria }\end{array}$} \\
\hline Context & Criterion & Gap & $\begin{array}{l}\text { Institutional } \\
\text { barrier }\end{array}$ & Rank \\
\hline $\begin{array}{l}\text { Cross-sector policy } \\
\text { coordination }\end{array}$ & $\begin{array}{l}\text { Coordination with other government departments and regu- } \\
\text { latory bodies }\end{array}$ & & & 9 \\
\hline \multirow{3}{*}{$\begin{array}{l}\text { Laws, rights and regulatory } \\
\text { instruments }\end{array}$} & Goal-based regulatory framework & & & 7 \\
\hline & Disclosure of hydraulic injection fluid & & & 8 \\
\hline & Compliance monitoring and enforcement & & & 3 \\
\hline Incentive framework & $\begin{array}{l}\text { An incentive framework (prices, subsidies, trade controls etc.) } \\
\text { that supports good groundwater management }\end{array}$ & & & 11 \\
\hline $\begin{array}{l}\text { Subsidiarity and local water } \\
\text { management }\end{array}$ & $\begin{array}{l}\text { A framework for subsidiarity and support to local water } \\
\text { management }\end{array}$ & & & 10 \\
\hline \multirow[t]{2}{*}{ Baseline measurements } & To detect groundwater pollution & & & 1 \\
\hline & To determine resource status & & & 5 \\
\hline Licences & Review of licences and setting conditions & & & 2 \\
\hline Transgressions & Dealing with non-compliant operators & & & 4 \\
\hline Prevention of pollution & Mitigation options in place & & & 6 \\
\hline
\end{tabular}


- A right to organise which includes access to appropriate financial mechanisms: South Africa has the necessary institutional mechanisms in the National Water Act to deal with water governance at various institutional levels, and at local, catchment and national levels. To date there has been limited success in setting up these institutions. If shale gas development moves forward the necessary institutional arrangements need to be set up with the necessary supporting financial mechanisms. The authors of this publication and others argue that a decentralised, polycentric, bottom-up approach, involving multiple institutions instead of a single global one, provides better conditions both for cooperation to thrive and for ensuring the maintenance of such institutions (Seward, 2013).

- Enabling legal, regulatory and financial systems. Legal, regulatory and financial systems that enable different types of organisations to form, and play effective roles in water management, are central to the evolution of pluralistic institutional contexts. In many situations, existing legal frameworks prescribe very specific organisational forms for activities such as groundwater management. They also allocate key financial mechanisms, such as the ability to charge fees or adopt local taxes, only to agencies within the governmental structure. Community-based organisations generally have no legal right to designate areas for management, raise funds from those benefiting from management, or take any action that either restricts or enables any form of use. As a result, it is impossible or difficult for them to develop the capacity to play an effective management role. This is frequently a shortcoming in the South African situation with unequal resources available for gas companies, landowners and communities which results in unequal power relations in forums.

- Water rights systems that balance public and private interests: The linkage between groundwater rights systems and the power to effect management in society has not been adequately explored. Rights systems that balance public and private interests - i.e., provide standing for both public and private perspectives on how groundwater should be allocated and used - would enable the types of institutional pluralism that this study contends are central to effective integration. Concepts such as private-use rights within a broad ownership of water held in public trust by the local governance body or the state may represent an avenue for this. Allocation of access - via linking the right to drill a well to land ownership, drilling regulations and well licences - is often practical. On the other hand, the introduction of volumetric allocation systems has proved difficult to implement for a variety of social and technical reasons. This is why debates over groundwater rights systems, a central feature of management debates in the 1990s, have made little practical progress. However, it is important to emphasize the inherent limitations and lack of balance in attempts to develop rights systems. In South Africa moves are afoot not to allow any temporary or permanent water trading.

- Systems for dispute resolution: If integration is an outcome based on contestation discussions within pluralistic institutional environments, then systems for dispute resolution are essential. South Africa has various mechanisms which include mediation and judicial review.

\section{CONCLUSIONS}

Prospective shale gas energy sources in South Africa have drawn interest from a number of international oil and gas operators. Therefore, it is critical to establish a practicable framework for groundwater governance and water resources protection. Governance challenges identified in this paper include: (a) setting baseline measurements to detect groundwater pollution and to determine resource status; (b) review of licences and setting conditions for the development of shale gas resources; (c) compliance monitoring and enforcement systems in place; (d) dealing punitively with non-compliant operators; (e) mitigation options in place to prevent groundwater pollution; (f) goalbased regulatory framework in place rather than a prescriptive regulatory framework; (g) disclosure of hydraulic injection fluid; (h) coordination with other government departments and regulatory bodies; (i) a framework for subsidiarity and support to local water management; and $(j)$ an incentive framework that supports good groundwater management. To overcome the challenges a decentralised, polycentric, bottom-up approach involving multiple institutions will be required to deal with shale gas development. This provides better conditions both for cooperation and collaboration to thrive and for ensuring the maintenance of such institutions. Thus, a pro-active groundwater governance structure that can accommodate current, near-term, and long-term shale gas development, is nimble enough to adapt to changes in energy development intensity/mechanisms, and cognisant of other stressors such as climate (e.g. drought), land-use changes, population growth, industry, and competing demands for water, is needed.

\section{ACKNOWLEDGEMENTS}

This paper is an outcome of research funded by the Water Research Commission (WRC) through the project entitled 'Unconventional gas exploration and mining and its impact on South Africa's water resources'. The authors acknowledge Dr Shafick Adams for supporting this project. Dr Levine's contribution to this work stemmed from a Fulbright Fellowship sponsored by WRC and participation in the National Science Foundation's (NSF) Independent Research and Development programme during her tenure. The views and opinions expressed in this paper are solely those of the authors and do not reflect policies of the WRC and the NSF. Mr Jude Cobbing reviewed the manuscript and is thanked for his contribution. The anonymous reviewers are also thanked for the time and effort in making a contribution to the paper.

\section{REFERENCES}

BRANTLEY SL (2015) Water resource impacts during unconventional shale-gas development: using publicly available data to understand the Pennsylvania experience. URL: http://extension.psu.edu/ natural-resources/water/courses/water-resource-webinars/webinars/ water-resource-impacts-during-unconventional-shale-gas-development-using-publicly-available-data-to-understand-the-pennsylvaniaexperience/pdf-copy-of-the-powerpoint (Accessed 6 February 2015).

BRAUNE E and ADAMS S (2013) Regional Diagnostic Report: SubSaharan Africa Region. WRC Report No. TT 578/13. Water Research Commission, Pretoria.

CIWEM (CHARTERED INSTITUTION OF WATER AND ENVIRONMENTAL MANAGEMENT) (2014) Shale gas and water: An independent review of shale gas exploration and exploitation in the UK with a particular focus on the implications for the water environment. The Chartered Institution of Water and Environmental Management, London. 
COOK P, BECK V, BRERETON D, CLARK R, FISHER S, KENTISH J, TOOMEY J and WILLIAMS J (2013) Engineering energy: unconventional gas production - a study of shale gas in Australia. Australian Council of Learned Academies, Melbourne.

CRANCH W, HOLDEN M, GOHO S and KONSCHNIK K (2014) Responding to landowner complaints of water contamination from oil and gas practices: Best practices. Harvard Law School, Cambridge.

DARRAH TH, VENGOSH A, JACKSON RB, WARNER NR and POREDA RJ (2014) Noble gases identify the mechanisms of fugitive gas contamination in drinking-water wells overlying the Marcellus and Barnett Shales. Proc. Natl. Acad. Sci. USA 111 14076-14081. http://dx.doi.org/10.1073/pnas.1322107111

DAVIES RJ, ALMOND S, WARD RS, JACKSON RB, ADAMS C, WORRALL F, HERRINGSHAW LG, GLUYAS J G and WHITEHEAD MA (2014) Oil and gas wells and their integrity: Implications for shale and unconventional resource exploitation. Mar. Petrol. Geol. 56 239-254. http://dx.doi.org/10.1016/j. marpetgeo.2014.03.001

DE WIT MJ (2011) The great shale debate in the Karoo. S. Afr. J. Sci. 107 9 pages.

DEPARTMENT OF MINES AND PETROLEUM (2013) Chemical disclosure guideline. Western Australia Department of Mines and Petroleum, Perth.

DEPARTMENT OF THE AUDITOR-GENERAL (2014) Department of Environmental Protection performance in monitoring potential impacts to water quality from shale gas development, 2009 - 2012. Commonwealth of Pennsylvania, Department of the Auditor General, Bureau of Special Performance Audits, Harrisburg.

DIXON-WOODS M (2011) Using framework-based synthesis for conducting reviews of qualitative studies. BMC Med. 9 1-2. http://dx.doi. org/10.1186/1741-7015-9-39

DROLLETTE BD, HOELZER K, WARNER NR, DARRAH TH, KARATUM O, O'CONNOR MP, NELSON RK, FERNANDEZ LA, REDDY CM, VENGOSH A, JACKSON RB, ELSNER M and PLATA DL (2015) Elevated levels of diesel range organic compounds in groundwater near Marcellus gas operations are derived from surface activities. Proc. Natl. Acad. Sci. 112 13184-13189. http://dx.doi. org/10.1073/pnas.1511474112

DWA (DEPARTMENT OF WATER AFFAIRS, SOUTH AFRICA) (2013) National Water Resource Strategy Second Edition. Department of Water Affairs, Pretoria.

DWS (DEPARTMENT OF WATER AND SANITATION, SOUTH AFRICA) (2015) Declaration of the exploration and or production of onshore naturally occurring hydrocarbons that requires stimulation, including but not limited to hydraulic fracturing and or underground gasification, to extract, and any activity incidental thereto that may impact detrimentally on the water resource as a controlled activity in terms of section 38(1) and publication of schedule of all controlled activities in terms of section 38 (4) of the National Water Act, 1998 (Act no. 36 of 1998). Government Gazette 39299. Government Printer, Cape Town.

ERCB (ENERGY RESOURCES CONSERVATION BOARD) (2013) Regulating uncoventional oil \& gas in Alberta. Energy Resources Conservation Board, Calgary.

FOSTER S and GARDUÑO H (2013) Groundwater-resource governance: Are governments and stakeholders responding to the challenge. Hydrogeol. J. 21 317-320. http://dx.doi.org/10.1007/ s10040-012-0904-9

FRACFOCUS (2014) About us. URL: http://fracfocus.org/welcome (Accessed 11 August 2014).

GALE NK, HEATH G, CAMERON E, RASHID $S$ and REDWOOD S (2013) Using the framework method for the analysis of qualitative data in multi-disciplinary health research. BMC Med. Res. Method. 13 1-8. http://dx.doi.org/10.1186/1471-2288-13-117

GALLEGOS TJ, VARELA BA, HAINES SS and ENGLE MA (2015) Hydraulic fracturing water use variability in the United States and potential environmental implications. Water Resour. Res. 51 5839-5845. http://dx.doi.org/10.1002/2015WR017278

GONZALEZ-CHAVEZ M, DAHI TALEGHANI A and OLSON JE (2015) A Cohesive model for modeling hydraulic fractures in naturally fractured formations. Society of Petroleum Engineers, Houston. http://dx.doi.org/10.2118/173384-ms
GSA (2012) Roadmap for unconventional gas projects in South Australia. Government of South Australia, Adelaide.

HICKENBOTTOM KL, HANCOCK NT, HUTCHINGS NR, APPLETON EW, BEAUDRY EG, XU P and CATH TY (2013) Forward osmosis treatment of drilling mud and fracturing wastewater from oil and gas operations. Desalination 312 60-66. http:// dx.doi.org/10.1016/j.desal.2012.05.037

HSIEH HF and SHANNON SE (2005) Three approaches to qualitative content analysis. Qual. Health Res. 15 1277-1288. http://dx.doi. org/10.1177/1049732305276687

IRGC (INTERNATIONAL RISK GOVERNANCE COUNCIL) (2013). Risk governance guidelines for unconventional gas development. International Risk Governance Council, Laussanne.

KGEG (KAROO GROUNDWATER EXPERT GROUP) (2013) Karoo Groundwater Atlas: Volume 2. SRK, Cape Town.

KNÜPPE K and PAHL-WOSTL C (2011) A Framework for the analysis of governance structures applying to groundwater resources and the requirements for the sustainable management of associated ecosystem services. Water Resour. Manage. 25 3387-3411. http://dx.doi. org/10.1007/s11269-011-9861-7

KOMNENIC A (2013) National Energy Board tells companies to publicly disclose hydraulic fracturing fluid recipes. Business Vancouver. URL: https://www.biv.com/article/2013/11/national-energy-boardtells-companies-to-publicly-/ (Accessed 27 January 2016).

KONSCHNIK KE and BOLING MK (2014) Shale gas development: a smart regulation framework. Environ. Sci. Technol. 48 8404-8416. http://dx.doi.org/10.1021/es405377u

LLEWELLYN GT, DORMAN F, WESTLAND JL, YOXTHEIMER D, GRIEVE P, SOWERS T, HUMSTON-FULMER E and BRANTLEY SL (2015) Evaluating a groundwater supply contamination incident attributed to Marcellus shale gas development. Proc. Natl. Acad. Sci. 112 6325-6330. http://dx.doi.org/10.1073/pnas.1420279112

MAULE AL, MAKEY CM, BENSON EB, BURROWS IJ and SCAMMELL MK (2013) Disclosure of hydraulic fracturing fluid chemical additives: analysis of regulations. New Solutions 23 167-187. http://dx.doi.org/10.2190/NS.23.1.j

MAUTER MS, ALVAREZ PJ, BURTON A, CAFARO DC, CHEN W, GREGORY KB, JIANG G, LI Q, PITTOCK J, REIBLE D and SCHNOOR JL (2014) Regional variation in water-related impacts of shale gas development and implications for emerging international plays. Environ. Sci. Technol. 48 8298-8306. http://dx.doi.org/10.1021/ es405432k

MCFEELEY M (2012) State hydraulic fracturing disclosure rules and enforcement: a comparison. Natural Resources Defense Council, Washington, DC.

MCGLADE C, SPEIRS J and SORRELL S (2013) Unconventional gas - a review of regional and global resource estimates. Energy 55 571-584. http://dx.doi.org/10.1016/j.energy.2013.01.048

MOENCH M, KULKARNI H and BURKE J (2012) Trends in local water management institutions. UNESCO, Paris.

MUIR A (2014) South African regulation of unconventional gas developments for the protection of precious water resources. Paper presented at: Unconventional Gas: Just the Facts, 18-19 August 2014, Pretoria.

O' BRIEN R, TALMA S and TREDOUX G (2013) The complexity of baseline monitoring in unconventional gas projects. Paper presented at: 13th Biennial Groundwater Division Conference and Exhibition, 17-19 September 2013, Durban.

OSTROM E (1999) Coping with tragedies of the commons. Annu. Rev. Polit. Sci. 2 493-535. http://dx.doi.org/10.1146/annurev.polisci.2.1.493

PENNY J, EATON A, BISHOP PG and BLOOMFIELD RE (2001) The Practicalities of Goal-Based Safety Regulation. Springer-Verlag, London.

PIETERSEN K, BEEKMAN H and HOLLAND M (2011) South African Groundwater Governance Case Study. WRC Report No. KV 273/11. Water Research Commission, Pretoria.

PIETERSEN K, BEEKMAN HE, HOLLAND M and ADAMS S (2012) Groundwater governance in South Africa: A status assessment. Water SA 38 (3) 453-460. http://dx.doi.org/10.4314/wsa.v38i3.11

PIETERSEN K, KANYERERE T and COBBING J (2014) Review of risks to water resources from unconventional gas exploration and production in South Africa and water science plan for unconventional gas development. Workshop summary, 3-4 July 2014, Cape Town. Water Research Commission, Pretoria. 
QUAST KW, LEVINE AD, KESTER JE and FORDHAM CL (2016) Forensic analysis of tertiary-butyl alcohol (TBA) detections in a hydrocarbon-rich groundwater basin. Environ. Monit. Assess. 188 208. http://dx.doi.org/10.1007/s10661-016-5193-7

ROWSELL DM and CONNAN J (1979) Oil generation, migration and preservation in the middle Ecca sequence near Dannhauser and Wakkerstroom. Geokongress: 77: Geol. Soc. S. Afr. Spec. Publ. 6 131-150.

ROWSELL DM and DE SWARDT AMJ (1976) Diagenesis in Cape and Karoo sediments, South Africa, and its bearing on their hydrocarbon potential. Trans. Geol. Soc. S. Afr. 79 81-145.

SEWARD P (2013). Key interventions to improve local groundwater governance. Second progress report, WRC project K5/2238. Water Research Commission, Pretoria.

SINGH A (2014) Regulatory perspectives on unconventional gas exploration and production. Workshop on risk to water resources from unconventional gas exploration and production, 3-4 July 2014, Cape Town.

SMIDT E and SATIJN B (2013) Groundwater governance: a decisive factor in resilience strategies. Water Governance Centre, Den Haag.

SRIVASTAVA A and THOMSON SB (2009) Framework analysis: a qualitative methodology for applied policy research. J Admin. Gov. 4 (2) 72-79.

STEYL G, VAN TONDER GJ and CHEVALLIER L (2012) State of the art - fracking for shale gas exploration in South Africa and the impact on water resources. WRC Report No. KV 294/11. Water Research Commission, Pretoria.
THE ROYAL SOCIETY AND THE ROYAL ACADEMY OF ENGINEERING (2012) Shale gas extraction in the UK: a review of hydraulic fracturing. The Royal Society and The Royal Academy of Engineering, London.

US EPA (UNITED STATES ENVIRONMENTAL PROTECTION AGENCY) (2015) Assessment of the potential impacts of hydraulic fracturing for oil and gas on drinking water resources. United States Environmental Protection Agency, Washington, DC.

VARADY RG, VAN WEERT F, MEGDAL SB, GERLAK A, ISKANDAR CA and HOUSE-PETERS L (2012) Groundwater Policy and Governance. FAO/Global Environment Facility, Paris.

VENGOSH A, JACKSON RB, WARNER N, DARRAH TH and KONDASH A (2014) A critical review of the risks to water resources from unconventional shale gas development and hydraulic fracturing in the United States. Environ. Sci. Technol. 48 8334-8348. http:// dx.doi.org/10.1021/es405118y

VIDIC RD, BRANTLEY SL, VANDENBOSSCHE JM, YOXTHEIMER $\mathrm{D}$ and ABAD JD (2013) Impact of shale gas development on regional water quality. Science 340 1235009. http://dx.doi.org/10.1126/ science. 1235009

WIJNEN M, AUGEARD B, HILLER B, WARD C and HUNTJENS P (2012) Understanding and Improving Groundwater Governance. World Bank, Washington, DC. 